\title{
GANTI RUGI DALAM PENYELESAIAN SENGKETA ANTARA JAMAAH UMROH DENGAN PT FIRST TRAVEL ATAS KEGAGALAN PEMBERANGKATAN UMROH
}

\author{
Lita Ayu, \\ Tri Setiady \\ Universitas Wiralodra \\ Email : litaayupuspita68@gmail.com, trisetiady@unwir.ac.id
}

\begin{abstract}
This research is based on the reality that occurs in the community that PT First Travel as the organizer of the Umrah pilgrimage trip (PPIU) violates Law Number 8 of 1999 and Regulation of the Minister of Religion Number 8 of 2018 so that it has resulted in losses to consumers of Umrah pilgrims. . PT First Travel does not carry out its obligations as a business actor and does not fulfill the consumer rights of the Umrah pilgrims. The legal relationship that begins with the sale and purchase agreement for Umrah travel services, consumers will depart as promised by PT First Travel, namely 6 months after payment is paid. However, this agreement was denied by PT First Travel so that they must be responsible for compensation to consumers for negligence and mistakes that resulted in the congregation failing to leave for Umrah. In this study, the method used in this case is the Normative Juridical approach method with data collection techniques by means of literature studies on legal materials, both primary legal materials, secondary legal materials and tertiary legal materials and field studies as a complement. The results of this study indicate that the responsibility of PT First Travel which is regulated in Law Number 8 of 1999 concerning Consumer Protection in providing compensation and / or compensation to consumers of Umrah pilgrims is not carried out by PT First Travel, and legal remedies are carried out in practice that occurred in the field of Umrah congregation consumers in defending their right to receive compensation ended in dispute resolution by filing a civil suit with the Depok District Court .
\end{abstract}

\section{Keywords : First Travel, Liability, Indemnity, Dispute Resolution}

\section{PENDAHULUAN}

Perkembangan perekonomian, perdagangan, dan perindustrian yang kian hari kian meningkat telah memberi kemanjaan yang luar biasa kepada konsumen karena ada beragam variasi produk barang dan/ jasa yang bisa dikonsumsi, dengan ini para pelaku usaha memanfaatkan peluang untuk memenuhi kebutuhan barang dan/ jasa baik secara jasmani maupun rohani. Pelaku usaha yang menjalankan bisnisnya dalam bentuk pelayanan jasa perjalanan atau travel, pada perkembangannya tidak hanya menyediakan paket perjalanan wisata, akan tetapi menyediakan juga paket perjalanan umrah. Biro perjalanan umroh merupakan usaha penyedia dan pelayanan jasa yang segala sesuatunya berhubungan dengan perjalanan ibadah umroh. Biro perjalanan umrah terlebih dahulu harus memperoleh izin dari Kementerian Agama sebagai Penyelenggara Perjalanan Ibadah Umrah. Menurut Peraturan Menteri Agama Nomor 8 Tahun 2018 tentang Penyelenggaraan 
Perjalanan Ibadah Umrah, Pasal 1 angka (2) menyebutkan Penyelenggara Perjalanan Ibadah Umroh yang selanjutnya disingkat PPIU adalah biro perjalanan wisata yang telah mendapat izin dari Menteri untuk menyelenggarakan perjalanan ibadah umroh.

PPIU menawarkan pelayanan jasa perjalanan umroh kepada masyarakat sebagai konsumen pengguna jasa tersebut. Hal ini akan menimbulkan hubungan hukum antara pelaku usaha dengan konsumen yang perlu dilindungi oleh ketentuan peraturan perundangundangan yakni Undang-Undang Nomor 8 Tahun 1999 Tentang Perlindungan Konsumen. Perlindungan konsumen mempunyai cakupan yang luas meliputi perlindungan konsumen dalam memperoleh barang dan jasa, yang berawal dari tahap kegiatan untuk mendapat barang dan jasa hingga ke akibat-akibat dari pemakaian barang dan jasa itu. Cakupan perlindungan konsumen dalam dua aspeknya yaitu, dapat dijelaskan sabagai berikut: ${ }^{1}$

1. Perlindungan terhadap kemungkinan diserahkan kepada konsumen barang dan atau jasa yang tidak sesuai dengan apa yang telah disepakati atau melanggar ketentuan undang-undang.

2. Perlindungan terhadap diberlakukannya kepada konsumen syarat-syarat yang tidak adil.

Terdapat salah satu pelaku usaha atau PPIU yang bermasalah yaitu PT First Anugerah Karya Wisata atau lebih dikenal dengan PT First Travel. Pendiri sekaligus pemilik PT First Travel adalah pasangan suami-istri yaitu Andika Surachman sebagai Presiden Direktur PT First Travel dan Anniesa Desvitasari Hasibuan sebagai Direktur PT First Travel. Paket promo umroh yang ditawarkan PT First Travel ini sangat murah sehingga berhasil menarik banyak calon jamaah yang mencapai 72.672 orang. Sejak Desember 2016 hingga Mei 2017, First Travel hanya mampu memberangkatkan 14.000 jamaah, sedangkan 58.682 calon jamaah lainnya merugi, dengan total nilai kerugian Rp848,7 miliar $^{2}$.

Berikut pelanggaran-pelanggaran yang dilakukan PT First Travel :

1) PT First Travel melanggar pasal 16 Undang-Undang Nomor 8 Tahun 1999 Tentang Perlindungan Konsumen yang berbunyi:

"Pelaku usaha dalam menawarkan barang dan/atau jasa melalui pesanan dilarang untuk :

\footnotetext{
1 Janus Sidabalok, Hukum Perlindungan Konsumen Di Indonesia, Cet. Ke-3, Citra Aditya Bakti, Bandung, 2014, hlm. 7.

2 Dian Cahyaningrum, Tanggung Jawab Hukum First Travel Dalam Kasus Penipuan, Penggelapan, Dan Pencucian Uang Dengan Modus Umrah, Majalah Info Hukum Singkat, Vol. IX, No. 16/II/Puslit/Agustus/2017, hlm. 2.
} 
a. Tidak menepati pesanan dan/atau kesepakatan waktu penyelesaian sesuai dengan yang dijanjikan;

b. Tidak menepati janji atas suatu pelayanan dan/atau prestasi."

2) PT First Travel telah melanggar Pasal 7 Undang-Undang Nomor 8 Tahun 1999 Tentang Perlindungan Konsumen yakni tidak melaksanakan kewajiban pelaku usaha sebagaimana mestinya.

Adapun Pasal 7 UUPK menyebutkan : ${ }^{3}$

"Kewajiban pelaku usaha adalah:

a. beritikad baik dalam melakukan kegiatan usahanya;

b. memberikan informasi yang benar, jelas dan jujur mengenai kondisi dan jaminan barang dan/atau jasa serta memberi penjelasan penggunaan, perbaikan dan pemeliharaan;

c. memperlakukan atau melayani konsumen secara benar dan jujur serta tidak diskriminatif;

d. menjamin mutu barang dan/atau jasa yang diproduksi dan/atau diperdagangkan berdasarkan ketentuan standar mutu barang dan/atau jasa yang berlaku;

e. memberi kesempatan kepada konsumen untuk menguji, dan/atau mencoba barang dan/atau jasa tertentu serta memberi jaminan dan/atau garansi atas barang yang dibuat dan/atau yang diperdagangkan;

f. memberi kompensasi, ganti rugi dan/atau penggantian atas kerugian akibat penggunaan, pemakaian dan pemanfaatan barang dan/atau jasa yang diperdagangkan; memberi kompensasi, ganti rugi dan/atau penggantian apabila barang dan/atau jasa yang diterima atau dimanfaatkan tidak sesuai dengan perjanjian."

3) PT First Travel telah melanggar Pasal 4 Undang-Undang Nomor 8 Tahun 1999 Tentang Perlindungan Konsumen yakni tidak memenuhi hak-hak konsumen sebagaimana mestinya.

Adapun Pasal 4 UUPK menyebutkan: ${ }^{4}$

a. hak atas kenyamanan, keamanan, dan keselamatan dalam mengkonsumsi barang dan/atau jasa;

b. hak untuk memilih barang dan/atau jasa serta mendapatkan barang dan/atau jasa tersebut sesuai dengan nilai tukar dan kondisi serta jaminan yang dijanjikan;

c. hak atas informasi yang benar, jelas, dan jujur mengenai kondisi dan jaminan barang dan/atau jasa;

d. hak untuk didengar pendapat dan keluhannya atas barang dan/atau jasa yang digunakan;

e. hak untuk mendapatkan advokasi, perlindungan, dan upaya penyelesaian sengketa perlindungan konsumen secara patut;

f. hak untuk mendapat pembinaan dan pendidikan konsumen;

g. hak untuk diperlakukan atau dilayani secara benar dan jujur serta tidak diskriminatif;

\footnotetext{
${ }^{3}$ Lihat Pasal 7 Undang-Undang Nomor 8 Tahun 1999 Tentang Perlindungan Konsumen.

${ }^{4}$ Lihat Pasal 4 Undang-Undang Nomor 8 Tahun 1999 Tentang Perlindungan Konsumen.
} 
h. hak untuk mendapatkan kompensasi, ganti rugi dan/atau penggantian, apabila barang dan/atau jasa yang diterima tidak sesuai dengan perjanjian atau tidak sebagaimana mestinya;

i. hak-hak yang diatur dalam ketentuan peraturan perundang-undangan lainnya.

4) PT First Travel telah melanggar Pasal 65 Peraturan Pemerintah Republik Indonesia Nomor 79 Tahun 2012 Tentang Pelaksanaan Undang-Undang Nomor 13 Tahun 2008 Tentang Penyelenggaraan Ibadah Haji yang berbunyi :

"PPIU dilarang menelantarkan jemaah umroh yang mengakibatkan jemaah umroh:

a. Gagal berangkat ke Arab Saudi;

b. Melanggar masa berlaku visa, atau;

c. Terancam keamanan dan keselamatannya."

5) PT First Travel telah melanggar Pasal 10 ayat 2 Peraturan Menteri Agama Nomor 8 Tahun 2018 Tentang Penyelenggaraan Perjalanan Ibadah Umroh yakni menetapkan biaya murah di bawah biaya penyelenggara ibadah umroh (BPIU) referensi yang berlaku.

Pasal 10 ayat 2 menyebutkan bahwa :

"Dalam hal PPIU menetapkan BPIU di bawah BPIU Referensi, PPIU wajib melaporkan secara tertulis kepada Direktur Jenderal."

Dalam fakta yang terjadi hingga tahun 2019 calon jamaah belum juga mendapatkan kompensasi/ganti rugi dari PT First Travel untuk diberangkatkan umroh atau mendapatkan kembali uang yang telah disetor. Pada tanggal 4 Maret 2019 calon jamaah mengajukan gugatan perdata ke Pengadilan Negeri Depok untuk mempertahankan hak-haknya dalam memperoleh ganti rugi, gugatan ini dilakukan setelah putusan Mahkamah Agung Nomor 3096 K/Pid.Sus/2018 dibacakan 31 Januari 2019 lalu, dalam putusan tersebut bahwa aset yang bernilai ekonomis dirampas untuk negara. Hal ini sebenarnya menunjukkan bahwa sengketa konsumen ini terlihat adanya sengkarut hukum dalam menyelesaikan perkara PT First Travel dengan jamaah umroh yang berujung pada ketidakpastian pada ganti kerugian yang harus diperoleh konsumen pengguna jasa layanan umroh ini.

Berdasarkan latar belakang tersebut di atas, maka peneliti tertarik untuk mengadakan penelitian dengan mengangkat judul : “Tinjauan Yuridis Terhadap Ganti Rugi Dalam Penyelesaian Sengketa Antara Jamaah Umroh Dengan Pt First Travel Atas Kegagalan Pemberangkatan Umroh Berdasarkan Undang-Undang Nomor 8 Tahun 1999 Tentang Perlindungan Konsumen". 


\section{PERMASALAHAN}

Berdasarkan latar belakang yang telah dijelaskan, maka permasalahan yang akan dibahas dalam penelitian ini sebagai berikut :

1. Bagaimana bentuk tanggungjawab atas ganti rugi PT First Travel terhadap jamaah umroh akibat gagal diberangkatkan menurut Undang-Undang Nomor 8 Tahun 1999 Tentang Perlindungan Konsumen?

2. Bagaimana upaya hukum yang bisa dilakukan konsumen Jemaah Umroh PT First Travel untuk menuntut ganti rugi menurut Undang-Undang Nomor 8 Tahun 1999 Tentang Perlindungan Konsumen ?

\section{METODE PENELITIAN}

Metode penelitian yang digunakan adalah penelitian hukum normatif (normatif legal research). Pengumpulan data dilakukan dengan cara studi kepustakaan. Data yang digunakan adalah data primer berdasarkan perundang-undangan dan data sekunder yang didapat dari bahan hukum primer, bahan hukum sekunder dan bahan hukum tersier. Data yang diperoleh kemudian dianalisis secara kualitatif dan dipaparkan secara deskriptif analitis.

\section{PEMBAHASAN}

\subsection{Bentuk Tanggungjawab Atas Ganti Rugi Pt First Travel Terhadap Jamaah} Umroh Akibat Gagal Diberangkatkan Menurut Undang-Undang Nomor 8 Tahun 1999 Tentang Perlindungan Konsumen

Merugikan pengguna jasa atau konsumen bertentangan dengan yang tertulis dalam Undang-Undang Nomor 8 Tahun 1999 tentang Perlindungan Konsumen yang selanjutnya ditulis UUPK. UUPK merupakan "payung" yang mengintegrasikan dan memperkuat penegakan hukum di bidang perlindungan konsumen ${ }^{5}$. Barang dan/atau jasa dalam penggunaannya dijamin akan nyaman, aman maupun tidak membahayakan konsumen penggunanya, maka konsumen diberikan hak untuk memilih barang dan/atau jasa yang dikehendakinya berdasarkan atas keterbukaan informasi yang benar, jelas, dan jujur. Jika terdapat penyimpangan yang merugikan, konsumen berhak untuk didengar, memperoleh advokasi, pembinaan, perlakuan yang adil, kompensasi ganti rugi ${ }^{6}$.

\footnotetext{
${ }^{5}$ Kurniawan, Hukum Perlindungan Konsumen : Problematika Kedudukan Dan Kekuatan Putusan Badan Penyelesaian Sengketa Konsumen (BPSK), UB Press, Malang, 2011, hlm 29.

${ }^{6}$ Gunawan Widjaja dan Ahmad Yani, Hukum tentang Perlindungan Konsumen, Cetakan ketiga, Gramedia Pustaka Utama, Jakarta, 2003, hlm 30.
} 
Penyimpangan yang dilakukan PT First Travel sebagai penyedia jasa layanan umroh seperti yang telah diuraikan sebelumnya mengakibatkan kerugian materill maupun immateriil bagi jamaah. Hal tersebut menimbulkann tanggung jawab PT First Travel yang harus dipikulnya. Tanggung jawab hukum ini erat kaitannya dengan hak dan kewajiban yang harus dipenuhi pelaku usaha. Tanggung jawab pelaku usaha di atur khusus dalam satu bab yaitu bab VI UUPK mulai dari pasal 19 sampai dengan pasal 28. Pasal 19 UUPK merumuskan tanggung jawab pelaku usaha yang berbunyi: ${ }^{7}$

(1) Pelaku usaha bertanggung jawab memberikan ganti rugi atas kerusakan, pencemaran, dan/atau kerugian konsumen akibat mengkonsumsi barang dan/atau jasa yang dihasilkan atau diperdagangkan.

(2) Ganti rugi sebagaimana dimaksud pada ayat (1) dapat berupa pengembalian uang atau penggantian barang dan/atau jasa yang sejenis atau setara nilainya, atau perawatan kesehatan dan/atau pemberian santunan yang sesuai dengan ketentuan peraturan perundang-undangan yang berlaku.

(3) Pemberian ganti rugi dilaksanakan dalam tenggang waktu 7 (tujuh) hari setelah tanggal transaksi.

(4) Pemberian ganti rugi sebagaimana dimaksud pada ayat (1) dan ayat (2) tidak menghapuskan kemungkinan adanya tuntutan pidana berdasarkan pembuktian lebih lanjut mengenai adanya unsur kesalahan.

(5) Ketentuan sebagaimana dimaksud pada ayat (1) dan ayat (2) tidak berlaku apabila pelaku usaha dapat membuktikan bahwa kesalahan tersebut merupakan kesalahan konsumen.

Berdasarkan ketentuan Pasal 19 UUPK yang telah dijelaskan di atas, dapat diketahui bahwa tanggung jawab pelaku usaha ini termasuk ke dalam pertanggung jawaban privat atau keperdataan yang bersifat dari hubungan kontraktual maupun di luar hubungan kontraktual. Dari kasus PT First Travel yang dibahas, menunjukan adanya hubungan kontraktual antara jamaah dengan PT First Travel maupun dari pihak agen sebagai perantara atas jasa yang diperdagangkan. Hubungan kontraktual ini timbul akibat dari hubungan hukum antara pelaku usaha dengan konsumen. Hubungan hukum antara PT First Travel dengan jamaah timbul karena ada hubungan jual beli jasa perjalanan umroh, sehingga mengakibatkan adanya hak dan kewajiban yang satu berhadapan dengan hak dan kewajiban pihak yang lain. Hubungan hukum tersebut sebagai hubungan hukum antara pelaku usaha dengan konsumen. adapun hubungan hukum antara PT First Travel dengan konsumen jamaah umroh memuat hak dan kewajiban yang diatur dalam ketentuan UUPK yakni pada pasal 4 memuat ketentuan hak konsumen dan pasal 5 memuat ketentuan kewajiban konsumen sedangkan pada pasal 6 memuat ketentuan hak konsumen dan pasal 7

\footnotetext{
${ }^{7}$ Lihat Pasal 19-28 Undang-Undang Nomor 8 Tahun 1999 Tentang Perlindungan Konsumen.
} 
memuat ketentuan kewajiban pelaku usaha. Adapun kewajiban pelaku usaha sebagai penyelenggara perjalanan ibadah umroh tercantum pada pasal 11 dan pasal 13 Peraturan Menteri Agama Nomor 8 Tahun 2018 Tentang Penyelenggaraan Perjalanan Ibadah Umroh.

Dalam hukum, khususnya hukum perdata, setiap tuntutan pertanggungjawaban harus mempunyai dasar, yaitu hal yang menyebabkan seseorang harus (wajib) bertanggung jawab, hal yang menyebabkan lahirnya kewajiban bertanggung jawab. Dasar pertanggungjawaban itu menurut hukum perdata ada dua yaitu: ${ }^{8}$

1. Pertanggungjawaban atas dasar kesalahan yaitu tanggung jawab yang dapat lahir karena terjadinya wanprestasi, timbulnya perbuatan melawan hukum, baik yang disebabkan karena perbuatan yang kurang hati-hati atau karena kesengajaan.

2. Pertanggungjawaban atas dasar resiko yaitu tanggung jawab yang harus dipikul sebagai resiko yang harus diambil oleh seorang pelaku usaha atas kegiatan usahanya.

Secara garis besar prinsip-prinsip tanggung jawab produk di dalam hukum perlindungan konsumen sebagai berikut: ${ }^{9}$

1) Prinsip tanggung jawab berdasarkan unsur kesalahan (fault liability atau liability based on fault). Prinsip ini menjelaskan bahwa seseorang baru dapat dimintakan pertanggung jawabannya secara hukum apabila ada unsur kesalahan yang dilakukan, dimaksudkan prinsip ini dengan harapan bahwa pelaku usaha yang berbuat kesalahan dan menimbulkan kerugian bagi konsumen harus memberikan ganti kerugian terhadap konsumen yang dirugikan, dan besar ganti rugi yang diberikan harus sebanding atau senilai dengan nilai kerugian yang di derita oleh konsumen;

Prinsip ini terdapat dalam KUHPerdata Pasal 1365, Pasal 1366, Pasal 1367, yang menyatakan seseorang baru dapat dimintakan pertanggungjawaban secara hukum jika ada unsur kesalahan yang dilakukan. Pasal 1365 KUHPerdata dikenal sebagai pasal Perbuatan Melawan Hukum. Adapun unsur pokok yang harus dipenuhi yaitu : adanya perbuatan; adanya unsur kesalahan; adanya kerugian yang diderita; adanya hubungan kausalitas antara kesalahan dan kerugian.

2) Prinsip praduga untuk selalu bertanggung jawab (presumption of liability principle). Prinsip ini menjelaskan bahwa tergugat selalu dianggap bertanggung jawab, sampai dia dapat membuktikan bahwa ia tidak bersalah, jadi beban pembuktian terdapat pada pihak tergugat dan hal tersebut sering dikenal dengan istilah beban pembuktian

\footnotetext{
${ }^{8}$ Janus Sidabalok, Op.Cit, hlm 90.

${ }^{9}$ Eli Wuria Dewi, Hukum Perlindungan Konsumen, Graha Ilmu, Yogyakarta, 2015, hlm. 76.
} 
terbalik. Meskipun demikian ketika prinsip ini diterapkan dalam kasus hukum perlindungan konsumen, maka asas praduga tak bersalah ini akan menjadi cukup relevan karena yang memiliki kewajiban untuk membuktikan kesalahan tersebut adalah pihak pelaku usaha bukan konsumen.

Prinsip ini terdapat dalam UUPK yang ditegaskan pada ketentuan Pasal 19, Pasal 22, Pasal 23 dan Pasal 28 UUPK mengenai beban pembuktian terbalik.

3) Prinsip praduga untuk tidak selalu bertanggung jawab (presumption of non liability principle). Prinsip ini hanya dikenal dalam transaksi konsumen yang sangat terbatas dan pembatasan yang demikian secara common sense dapat dibenarkan.

4) Prinsip tanggung jawab mutlak (strict liability). Adapun yang menjadi alasan-alasan prinsip ini diterapkan dalam hukum tentang product liability:

a. Di antara konsumen atau korban di satu pihak dan produsen di lain pihak, di antara kedua pihak tersebut beban kerugian seharusnya ditanggung oleh pihak yang memproduksi dan/atau mengeluarkan barang-barang cacat atau berbahaya tersebut dipasarkan;

b. Dengan menempatkan atau mengedarkan barang-barang di pasaran;

c. Tanpa harus menerapkan prinsip ini, pelaku usaha yang melakukan kesalahan dapat dituntut melalui proses penuntutan beruntun.

5) Prinsip tanggung jawab dengan pembatasan (limitation of liability), prinsip ini merupakan salah satu prinsip yang digemari oleh pelaku usaha untuk dicantumkan sebagai klausula eksonerasi di dalam perjanjian standar yang dibuatnya secara sepihak, untuk membatasi maksimal tanggung jawab yang diberikan kepada konsumen.

Problematika kegagalan pemberangkatan umroh yang terjadi, PT First Travel berkewajiban melaksanakan tanggungjawabnya sesuai dengan ketentuan Pasal 19 UUPK. Artinya, PT First Travel wajib memberikan ganti rugi berupa pengembalian uang (refund) maupun untuk penggantian jasa yang sejenis. Apabila ganti rugi dalam bentuk penggantian jasa yang sejenis atau memberangkatkan jamaah umroh, PT First Travel tidak memiliki izin operasional sebagai PPIU karena telah dicabut Kemenag RI berdasarkan Keputusan Menteri Agama (KMA) Nomor 589 Tahun 2017 per tanggal 1 Agustus 2017, artinya jamaah umroh dapat diberangkatkan melalui biro penyelenggara umroh yang lain dengan biaya yang ditanggung oleh PT First Travel. Dari jumlah calon jamaah yang terdaftar di First Travel mencapai 72.672 orang. Sejak Desember 2016 hingga Mei 2017, First Travel 
hanya mampu memberangkatkan 14.000 jamaah, sedangkan 58.682 calon jamaah lainnya merugi. Dengan demikian, jamaah umroh berhak mendapatkan haknya berupa kompensasi dan/ganti kerugian dari PT First Travel menurut ketentuan UUPK karena lahir dari hubungan hukum antara pelaku usaha dengan konsumen sebagai bentuk perlindungan terhadap konsumen sebagaimana yang telah diamanatkan oleh UUPK.

\subsection{Upaya Hukum Yang Bisa Dilakukan Konsumen Jemaah Umroh PT First Travel Untuk Menuntut Ganti Rugi Menurut Undang-Undang Nomor 8 Tahun 1999 Tentang Perlindungan Konsumen}

Upaya hukum adalah langkah hukum yang ditempuh subyek hukum atas pihakpihak yang menyatakan keberatan atas suatu perkara, baik itu perkara yang masih berlangsung maupun telah diputuskan pengadilan. Tujuan upaya hukum tersebut ialah permintaan ke pengadilan agar memutuskan sesuai dengan kepentingan hukum atau hak yang mengajukan ${ }^{10}$. Kepentingan hak yang diajukan dalam hal ini sengketa antara konsumen dengan pelaku usaha, sebenarnya telah di atur pula pada ketentuan pasal 23, pasal 28, pasal 45, pasal 47, pasal 48 UUPK yang berhubungan dengan penyelesaian sengketa konsumen.

Menurut UUPK pada BAB X tentang penyelesaian sengketa diatur secara tegas pada ketentuan pasal 45 yang berbunyi :

(1) Setiap konsumen yang dirugikan dapat menggugat pelaku usaha melalui lembaga yang bertugas menyelesaikan sengketa antara konsumen dan pelaku usaha atau melalui peradilan yang berada di lingkungan peradilan umum.

(2) Penyelesaian sengketa konsumen dapat ditempuh melalui pengadilan atau diluar pengadilan berdasarkan pilihan sukarela para pihak yang bersengketa.

(3) Penyelesaian sengketa di luar pengadilan sebagaimana dimaksud pada ayat (2) tidak menghilangkan tanggung jawab pidana sebagaimana diatur dalam Undang-undang.

(4) Apabila telah dipilih upaya penyelesaian sengketa konsumen di luar pengadilan, gugatan melalui pengadilan hanya dapat ditempuh apabila upaya tersebut dinyatakan tidak berhasil oleh salah satu pihak atau oleh para pihak yang bersengketa.

\subsection{Upaya Hukum Penyelesaian Sengketa di Luar Pengadilan}

1) Penyelesaian sengketa dengan jalan damai

Penyelesaian sengketa konsumen pada pasal 45 ayat (2) jo pasal 47 tidak menutup kemungkinan penyelesaian damai oleh para pihak yang bersengketa. Pada setiap tahap

${ }^{10}$ V. Harlen Sinaga, Hukum Acara Perdata Dengan Pemahaman Hukum Materiil, Jakarta, Erlangga, 2015, hlm. 266. 
diusahakan untuk menggunakan penyelesaian damai oleh kedua belah pihak yang bersengketa. Yang dimaksud dengan penyelesaian secara damai adalah penyelesaian yang dilakukan oleh kedua belah pihak yang bersengketa (pelaku usaha dan konsumen) tanpa melalui pengadilan atau badan penyelesaian sengketa konsumen dan tidak bertentangan dengan Undang-undang ini. Penyelesaian sengketa secara damai dilakukan sebelum pihak bersengketa menempuh jalur melalui BPSK atau badan peradilan ${ }^{11}$.

2) Penyelesaian sengketa melalui Badan Penyelesaian Sengketa Konsumen (BPSK)

Menurut ketentuan Pasal 47 UUPK Penyelesaian sengketa konsumen di luar pengadilan diselenggarakan untuk mencapai kesepakatan mengenai bentuk dan besarnya ganti rugi dan/atau mengenai tindakan tertentu untuk menjamin tidak akan terjadi kembali atau tidak akan terulang kembali kerugian yang diderita oleh konsumen. Mekanisme penyelesaian sengketa konsumen di luar pengadilan dapat ditempuh dengan mengajukan pengaduan atau gugatan atas kerugian yang diderita melalui Badan Penyelesaian Sengketa Konsumen (BPSK) diselesaikan dalam bentuk mediasi, konsiliasi maupun arbitrase sesuai pilihan sukarela dari pihak yang bersengketa. BPSK merupakan lembaga yang bertugas dan berwenang menyelesaikan sengketa antara pelaku usaha dengan konsumen sebagaimana diatur dalam ketentuan Pasal 52 UUPK. Dengan adanya BPSK maka penyelesaian sengketa konsumen dapat dilakukan secara cepat, mudah dan murah. Karena undang-undang menentukan dalam tenggang waktu 21 hari kerja BPSK wajib memberikan putusannya (Pasal 55 UUPK).

Melihat fakta yang terjadi, konsumen jamaah umroh ini tidak melakukan pengaduan kepada BPSK melainkan kepada Kementerian Agama RI terkait keluhan jadwal keberangkatan yang umroh yang tidak jelas pada tahun 2017. Artinya Kementerian Agama RI ini mengagendakan mediasi antara pihak First Travel dengan calon jamaah dan agen sejak 18 April 2018. Upaya mediasi ini dilakukan hingga beberapa kali namun tidak ada panggilan satu pun yang dihadiri pihak PT First Travel. Hal ini, penyelesaian sengketa melalui mediasi pun gagal dan ganti rugi belum dapat diperoleh.

\subsection{Upaya Hukum Penyelesaian Sengketa Melalui Pengadilan}

Berdasarkan ketentuan Pasal 48 UUPK Penyelesaian sengketa konsumen melalui pengadilan mengacu pada ketentuan tentang peradilan umum yang berlaku dengan memperhatikan ketentuan dalam Pasal 45. Di dalam Pasal 45 ayat (4) gugatan melalui Pengadilan dilakukan manakala penyelesaian sengketa konsumen di luar pengadilan

\footnotetext{
${ }^{11}$ Penjelasan Undang-Undang Nomor 8 Tahun 1999 Tentang Perlindungan Konsumen.
} 
dinyatakan tidak berhasil oleh salah satu pihak atau oleh para pihak yang bersengketa Dengan demikian, hukum acara pada peradilan umum ini berdasarkan pada Herziene Inlandsch Reglement (HIR) atau Rechtsreglemen Buitengewesten (R.Bg).

Pengajuan gugatan yang berlaku dalam hukum positif Indonesia yaitu dikenal dengan asas Hakim bersifat pasif, hal ini berarti pihak-pihak yang mempunyai kepentingan hak akibat kerugian yang diderita dapat mengajukan gugatan seperti dalam pasal 1365 KUHPerdata yaitu setiap orang yang mendalilkan bahwa ia mempunyai sesuatu hak atau guna meneguhkan haknya sendiri maupun membantah suatu hak orang lain, menunjuk pada suatu peristiwa, diwajibkan membuktikan adanya hak atau peristiwa tersebut. Kemudian dapat dilihat bahwa dalam rumusan pasal $1865 \mathrm{KUH}$ Perdata tersebut mengandung beberapa makna, yang mana makna tersebut terdiri dari: ${ }^{12}$

a) Seseorang dapat mengajukan suatu peristiwa, dalam hal ini wanprestasi atau perbuatan melawan hukum, untuk menunjukkan haknya.

b) Peristiwa yang diajukan itu harus dibuktikan.

Sedangkan menurut Pasal 46 UUPK gugatan atas pelanggaran pelaku usaha dapat dilakukan oleh :

a) seorang konsumen yang dirugikan atau ahli waris yang bersangkutan;

b) sekelompok konsumen yang mempunyai kepentingan yang sama;

c) lembaga perlindungan konsumen swadaya masyarakat;

d) pemerintah dan/atau instansi terkait.

Berhubung dengan kasus PT First Travel yang merugikan ribuan calon jamaah umroh, akan lebih efektif apabila jamaah umroh mengajukan gugatan perwakilan kelompok (class action). Gugatan Pewakilan Kelompok sesuai ketentuan Pasal 1 huruf a Peraturan Mahkamah agung (PERMA) Nomor 1 Tahun 2002 tentang Acara Gugatan Perwakilan Kelompok adalah suatu tata cara pengajuan gugatan dalam mana satu orang atau lebih yang mewakili kelompok mengajukan gugatan untuk diri sendiri dan sekaligus mewakili sekelompok orang yang jumlahnya banyak, yang memiliki kesamaan fakta atau dasar hukum antara wakil kelompok dan anggota kelompok yang dimaksud. Prosedur gugatan class action sebagaimana yang diatur dalam UUPK terutama menyangkut kerugian-kerugian konsumen yang bersifat massal, telah membuka akses konsumen untuk 12 Redaksi Aksara, Kitab Undang-Undang Hukum Perdata, Redaksi Aksara Sukses, Yogyakarta, 2013, hlm
470. 
mendapatkan keadilan (consumer access to justice) ${ }^{13}$. Butir 3e Resolusi Majelis Umum Perserikatan Bangsa-Bangsa tanggal 16 April 1985 Nomor A/RES/39/248 tentang Pedoman Perlindungan Konsumen (Guidelines for Cunsumer Protection) mengetengahkan salah satu kebutuhan konsumen yang harus diupayakan pemerintah, yaitu tersedianya penyelesaian ganti rugi yang efektif ${ }^{14}$. Gugatan perwakilan kelompok ini diakui pula oleh Pasal 46 UUPK.

Sengketa konsumen jamaah umroh dengan PT First Travel belum menemukan solusi dalam penyelesaian perkara tersebut. Upaya hukum sebagai langkah terakhir yang dilakukan jamaah umroh untuk melindungi kepentingan haknya yang belum dipenuhi PT First Travel yakni mengajukan gugatan secara perdata kepada Pengadilan Negeri Depok dengan Nomor Perkara 52/Pdt.G/2019/PN.Dpk, gugatan ini diajukan terhadap hasil putusan Mahkamah Agung Nomor 3096 K/Pid.Sus/2018. Kasus sengketa konsumen yang bermula dari keperdataan yang berasal dari hubungan pelaku usaha dengan konsumen, namun diproses secara pidana membuat aset PT First Travel harus dirampas negara, sehingga dari putusan MA tersebut jamaah menggugat secara perdata dengan harapan uang jamaah dapat dikembalikan sebagai hak milik dari aset yang dimiliki PT First Travel.

Gugatan perdata diajukan konsumen jamaah umroh ke Pengadilan Negeri Depok dalam nomor perkara 52/Pdt.G/2019/PN.Dpk pada 4 Maret 2019 lalu. Penggugat yang diwakili oleh Anny Suhartaty, Hj. Ira Faizah, Devi Kusrini, Zuherial, Ir. Ario Tedjo Dewanggono mengajukan gugatan kepada Andika Surachman dengan Turut Tergugat Kepala Kejaksaan Agung Republik Indonesia cq Kepala Kejaksaan Negeri Depok. Penggugat menuntut ganti kerugian materiil sebesar Rp 49.075.199.560 (empat puluh sembilan milyar tujuh puluh lima juta seratus sembilan puluh sembilan ribu lima ratus enam puluh rupiah) dan kerugian immateriil yang mana jamaah telah lama menunggu untuk diberangkatkan ke Baitullah, sehingga besar harapan jamaah agar dengan adanya upaya hukum ini, keinginan jamaah untuk berangkat umroh dapat terlaksana dalam waktu dekat. Gugatan perdata tersebut dibacakan putusannya oleh Pengadilan Negeri Depok pada 2 Desember 2019 dengan amar putusan : Menyatakan gugatan Para Penggugat tidak dapat diterima (Niet ontvankelijke verklaard) dan Menghukum Para Penggugat untuk membayar

\footnotetext{
${ }^{13}$ Yusuf Shofie, Kapita Selekta Hukum Perlindungan Konsumen di Indonesia, Citra Aditya Bakti, Bandung, 2008, hlm 295.

${ }^{14} \mathrm{Ibid}$, hlm 297.
} 
biaya perkara yang timbul dalam perkara ini secara tanggung renteng yang sampai saat ini sejumlah Rp 811.000,- (delapan ratus sebelas ribu rupiah) ${ }^{15}$.

Bila putusan yang dinyatakan NO oleh hakim dilihat dari unsur-unsur gugatan perwakilan kelompok (class action), maka terdapat beberapa unsur yang belum terpenuhi sehingga gugatan tersebut tidak dapat diterima. Adapun unsur-unsur class action sebagai berikut: ${ }^{16}$

1) gugatan secara perdata;

2) wakil kelompok (class representatif);

3) anggota kelompok (class member);

4) adanya kerugian yang nyata-nyata diderita;

5) kesamaan peristiwa atau fakta dan dasar hukum.

Kelima penggugat yang menjadi perwakilan dalam gugatan perdata yang dilayangkan ke PN Depok, dimana Penggugat I, Penggugat II, dan Penggugat III adalah agen, Pengugat IV dan Penggugat V adalah jamaah First Travel yang gagal berangkat umroh. Maka penggugat yang terdiri agen ini berada di pihak tergugat. Sehingga Penggugat (agen) yang menjadi wakil kelompok dinilai keliru sebagai Penggugat dan tidak memiliki kepentingan hukum dalam hal kerugian yang nyata-nyata diderita.

Kekeliruan bertindak sebagai Penggugat maupun Tergugat dapat mengakibatkan gugatan tersebut mengandung cacat formil. Cacat formil dalam manentukan pihak Penggugat maupun Tergugat dinamakan Error in Persona. Secara konvensional hak gugat hanya bersumber pada prinsip "tiada gugatan tanpa kepentingan hukum" (point d'interest point d'action). Kepentingan hukum (legal interest) yang dimaksud di sini adalah merupakan kepentingan yang berkaitan dengan kepemilikan (propietary interest) atau kepentingan material berupa kerugian yang dialami secara langsung (injury in fact). Asas point d'interest point d'action berhubungan erat dengan asas legitima persona standi in judicio, yakni kecakapan atau kewenangan untuk bertindak di depan pengadilan selaku pihak, baik selaku pihak Penggugat maupun selaku pihak Tergugat ${ }^{17}$.

Menentukan siapa yang akan menjadi wakil kelas merupakan aspek penting dalam gugatan class action, terdapat sejumlah kualifikasi untuk menentukan wakil kelas. Hal ini penting karena wakil kelas memiliki arti penting dalam mempengaruhi dikabulkan atau

\footnotetext{
15 Sistem Informasi Penelusuran Perkara, dalam http://sipp.pn-depok.go.id/list_perkara/search. Diakses 1 agustus 2020 pukul 11.00 WIB.

${ }^{16}$ Erry Meta, Gugatan Class Action, dalam https://errymeta.wordpress.com/artikel/artikel-perdata/gugatanclass-action/. Diakses 3 September 2020 pukul 14.00 WIB

${ }^{17}$ Sudikno Mertokusumo, Hukum Acara Perdata Indonesia, Liberty, Yogyakarta, 1988, hlm 53.
} 
tidak dikabulkannya gugatan yang diajukan dan berkaitan dengan kemampuan untuk mengelola kelas ${ }^{18}$. Berdasarkan PERMA kapasitas yang dimiliki wakil kelompok adalah memiliki hak dan kewenangan sebagai kuasa kelompok. Tanpa menggunakan surat kuasa khusus dari anggota kelompok, dan tanpa memerlukan persetujuan dari anggota kelompok, demi hukum bertindak sebagai wakil kelompok ${ }^{19}$.

\section{PENUTUP}

\subsection{Simpulan}

Berdasarkan uraian dari penelitian di atas, maka dapat ditarik kesimpulan sebagai berikut :

1. Bentuk tanggungjawab PT First Travel atas ganti rugi terhadap konsumen jamaah umroh berkewajiban melaksanakan tanggungjawabnya sesuai dengan ketentuan Pasal 19 UUPK. Artinya, PT First Travel wajib memberikan ganti rugi berupa pengembalian uang (refund) maupun untuk penggantian jasa yang sejenis yakni memberangkatkan jamaah umroh, namun PT First Travel tidak memiliki izin operasional sebagai PPIU karena telah dicabut Kemenag RI yang artinya jamaah umroh diberangkatkan melalui biro penyelenggara umroh yang lain dengan biaya yang ditanggung oleh PT First Travel. PT First Travel harus bertanggung jawab kepada jamaah umroh dengan pertanggungjawaban atas dasar kesalahan yang telah menimbulkan wanprestasi serta perbuatan melawan hukum.

2. Upaya Hukum yang bisa dilakukan konsumen untuk menuntut ganti rugi menurut Undang-Undang Nomor 8 Tahun 1999 Tentang Perlindungan Konsumen, pada BAB $\mathrm{X}$ tentang penyelesaian sengketa diatur secara tegas pada ketentuan pasal 45 ayat (1). Upaya hukum penyelesaian sengketa dapat diselesaikan melalui pengadilan maupun di luar pengadilan. Karena sengkarut hukum terjadi dalam perkara ini, konsumen jamaah umroh melakukan upaya hukum dengan mengajukan gugatan class action kepada Pengadilan Negeri Depok.

\subsection{Saran}

Berdasarkan uraian dari simpulan di atas, maka dapat dikeukakan saran sebagai berikut :

\footnotetext{
${ }^{18}$ Harjono, Bahan Kuliah Hukum Acara Class Action, dalam https://jurnal.uns.ac.id dikutip dari Jurnal Verstek Vol. 1 No. 3, 2013. Diunduh 3 September 2020 pukul 16.00 WIB.

19 Yahya Harahap, Hukum Acara Perdata tentang Gugatan, Persidangan, Penyitaan, Pembuktian, dan Putusan Pengadilan, Jakarta, Sinar Grafika, 2012, hlm 146.
} 
1. Pemerintah diharapkan memperketat pengawasan terhadap agen-agen travel khususnya agen travel jamaah umroh sebab oomatis akan beraviliasi dengan banyak masyarakat dan kasus PT First Travel yang telah menimbulkan wanprestasi serta perbuatan melawan hukum tidak kembali terjadi.

2. Undang-undang perlindungan konsumen sudah mengantisipasi kejadian seperti ini, namun akan lebih baik lagi jika para penegak hukum dapat menjalankan tugasnya dengan lebih baik dan professional.

\section{DAFTAR PUSTAKA}

\section{A. Buku}

Eli Wuria Dewi, Hukum Perlindungan Konsumen, Graha Ilmu, Yogyakarta, 2015, hlm 76.

Harlen Sinaga, Hukum Acara Perdata Dengan Pemahaman Hukum Materiil, Jakarta, Erlangga, 2015, hlm 266.

Gunawan Widjaja dan Ahmad Yani, Hukum tentang Perlindungan Konsumen, Cetakan ketiga, Gramedia Pustaka Utama, Jakarta, 2003, hlm 30.

Kurniawan, Hukum Perlindungan Konsumen : Problematika Kedudukan Dan Kekuatan Putusan Badan Penyelesaian Sengketa Konsumen (BPSK), UB Press, Malang, 2011, hlm 29.

Janus Sidabalok, Hukum Perlindungan Konsumen Di Indonesia, Cet. Ke-3, Citra Aditya Bakti, Bandung, 2014, hlm 7.

Redaksi Aksara, Kitab Undang-Undang Hukum Perdata, Redaksi Aksara Sukses, Yogyakarta, 2013, hlm 470.

Sudikno Mertokusumo, Hukum Acara Perdata Indonesia, Liberty, Yogyakarta, 1988, hlm 53.

Yusuf Shofie, Kapita Selekta Hukum Perlindungan Konsumen di Indonesia, Citra Aditya Bakti, Bandung, 2008, hlm 295.

Yahya Harahap, Hukum Acara Perdata tentang Gugatan, Persidangan, Penyitaan, Pembuktian, dan Putusan Pengadilan, Jakarta, Sinar Grafika, 2012, hlm 146. 


\section{B. Jurnal}

Dian Cahyaningrum, Tanggung Jawab Hukum First Travel Dalam Kasus Penipuan, Penggelapan, Dan Pencucian Uang Dengan Modus Umrah, Majalah Info Hukum Singkat, Vol. IX, No. 16/II/Puslit/Agustus/2017, hlm 2.

Erry Meta, Gugatan Class Action, dalam https://errymeta.wordpress.com/artikel/artikelperdata/gugatan-class-action/. Diakses 3 September 2020 pukul 14.00 WIB

Harjono, Bahan Kuliah Hukum Acara Class Action, dalam https://jurnal.uns.ac.id dikutip dari Jurnal Verstek Vol. 1 No. 3, 2013. Diunduh 3 September 2020 pukul 16.00 WIB.

\section{Undang-undang}

Peraturan Menteri Negara Republik Indonesia Nomor 8 Tahun 2018 tentang Penyelenggaraan Perjalanan Ibadah Umrah

Peraturan Mahkamah Agung (PERMA) Nomor 1 Tahun 2002 tentang Acara Gugatan Perwakilan Kelompok

Pelaksanaan Undang-Undang Nomor 13 Tahun 2008 Tentang Penyelenggaraan Ibadah Haji

Undang-Undang Nomor 8 Tahun 1999 Tentang Perlindungan Konsumen

Peraturan Pemerintah Republik Indonesia Nomor 79 Tahun 2012 Tentang

\section{Website}

Sistem Informasi Penelusuran Perkara, dalam http://sipp.pndepok.go.id/list_perkara/search. Diakses 1 agustus 2020 pukul 11.00 WIB. 